\title{
High-performance liquid chromatographic measurement of amiodarone and desethylamiodarone in small tissue samples after enzymatic digestion
}

\author{
GCA STOREY,${ }^{*}$ PC ADAMS,$\uparrow$ RWF CAMPBELL,$\dagger$ DW HOLT $*$ \\ From the *Poisons Unit, Guy's Hospital, London, SE1, and the †Academic Department of Cardiology, \\ Freeman Hospital, Newcastle upon Tyne
}

SUMMARY A method is described for the measurement of amiodarone and desethylamiodarone in small tissue samples. With the exception of fat, for which lipase is used, the tissues are digested with a proteolytic enzyme. After the addition of an internal standard the analytes are extracted from the homogeneous digest into an organic solvent and measured by high-performance liquid chromatography (HPLC) with UV detection at $240 \mathrm{~nm}$. The method shows good reproducibility using tissue samples as small as $20 \mathrm{mg}$ and suggests extensive accumulation of both compounds in some tissues, with particularly high concentrations in tissues associated with adverse effects of the drug.

Amiodarone is a class III antiarrhythmic agent ${ }^{1}$ and in humans treated chronically with the drug the formation of a major metabolite, desethylamiodarone, has been demonstrated. ${ }^{2}$ The development of an HPLC assay for the measurement of amiodarone in plasma $^{3}$ has shown that the drug has an exceptionally long terminal half-life of elimination, (of the order of 50 days $)^{4}$ and a very large volume of distribution (approximately 50001 ). ${ }^{5}$ Data on the tissue distribution of this drug are sparse, being confined to preliminary studies using radiolabelled drug $^{6}$ and a study in rat tissue after single, intravenous, dosage in which few details of tissue preparation prior to HPLC analysis are given.'

In an effort to characterise the tissue distribution of the drug and its desethyl metabolite we have developed a method for their measurement in small (20-100 mg) tissue samples collected at necropsy or at biopsy. The method involves enzymatic digestion of the tissue samples, appropriate dilution of the digest in analyte-free human plasma, addition of an internal standard and extraction into methyl tertbutyl ether. An aliquot of the organic phase is then analysed by HPLC with UV detection.

\section{Material and methods}

MATERIAL AND REAGENTS

Amiodarone hydrochloride, desethylamiodarone Accepted for publication 3 February 1983 oxalate and L8040 (internal standard) were obtained from Labaz (Brussels, Belgium); their chemical structures are shown in Fig. 1. Fenethazine hydrochloride (internal standard) was obtained from Rhone-Poulenc (Paris, France). Lyophilised Subtilisin A was obtained from Novo Industri A/S (Copenhagen, Denmark), and Lipase, type II Crude from porcine pancreas, was obtained from Sigma Chemical Company (Bournemouth, UK). These enzymes were used as $2 \mathrm{mg} / \mathrm{l}$ and $10 \mathrm{mg} / \mathrm{l}$ solutions, respectively, prepared in $0.07 \mathrm{M}$ phosphate buffer pH 7.4. Methanol, 2,2,4-trimethyl pentane and methyl tert-butyl ether, all HPLC grade, were obtained from Rathburn Chemicals (Walkerburn, UK). Potassium bromide and sodium dihydrogen orthophosphate were analytical grade reagents.

\section{HIGH-PERFORMANCE LIQUID \\ CHROMATOGRAPHY}

The solvent delivery system was a constant-flow reciprocating pump (Applied Chromatography Systems, Model 750/03) and sample injection was performed using a Rheodyne Model 7125 syringeloading valve fitted with a $100 \mu$ l loop. Stainless steel tubing $(0.25 \mathrm{~mm}$ ID) was used to connect the outlet port of the valve to the analytical column, a stainless-steel tube $125 \times 5 \mathrm{~mm}$ ID packed with Spherisorb 5 Silica (Hichrom, Woodley, UK) which was used at ambient temperature (normally $22^{\circ} \mathrm{C}$ ). The column effluent was monitored at $240 \mathrm{~nm}$ 
<smiles>CCN(CC)CCCOc1c(I)cc(C(=O)c2c(C)oc3ccccc23)cc1I</smiles>

Amiodarone

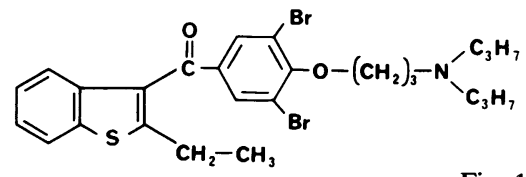<smiles>CCNCCCOc1c(I)cc(C(=O)c2c(C)oc3ccccc23)cc1I</smiles>

Fig. 1 Chemical structure of amiodarone, $\overrightarrow{0}$ desethylamiodarone and L 8040.

(Applied Chromatography Systems, Model 750/11) and integration of peak areas was performed using a Hewlett-Packard 3352 data system. The mobile phase consisted of methanol: 2,2,4-trimethyl pentane: methyl tert-butyl ether $(80: 10: 10)$ containing $6 \mathrm{mmol} / \mathrm{l}$ potassium bromide and was delivered at a flow-rate of $2.0 \mathrm{ml} / \mathrm{min}$. For the analysis of rabbit tissue digest a mobile phase consisting of methanol: diethyl ether $(85: 15)$ containing perchloric acid $(0.02 \% \mathrm{vol} / \mathrm{vol})$ was used to facilitate the separation of the analytes from endogenous material.

The chromatography of an extract from a heparinised human plasma standard containing amiodarone, desethylamiodarone, L8040 and fenethazine on this system is illustrated in Fig. 2.

\section{TISSUE DIGESTION}

To a preweighed $10 \mathrm{ml}$ tapered glass test-tube about $100 \mathrm{mg}$ wet weight of blotted tissue was added and the exact weight determined. Enzyme solution (1 $\mathrm{ml}$ ) was added to the tube, (lipase for fat tissue, Subtilisin A for all others), which was then sealed with a ground-glass stopper and incubated at $50^{\circ} \mathrm{C}$ for $16 \mathrm{~h}$. Subsequently, the contents of the tube were vortex mixed to yield a homogeneous suspension. To the fat digest approximately $4 \mathrm{mg}$ of sodium lauryl sulphate was added before vortex mixing to give a more stable homogeneous mixture.

\section{EXTRACTION PROCEDURE}

To a small glass (Dreyer) test tube, $100 \mu \mathrm{l}$ of tissue digest, $100 \mu \mathrm{l}$ of analyte-free human plasma, $20 \mu \mathrm{l}$ of $0.05 \mathrm{mmol}$ fenethazine in $2 \mathrm{M}$ sodium dihydrogenorthophosphate and $200 \mu$ methyl tert-butyl ether were added. To digests of fat tissue $20 \mu \mathrm{l}$ of 0.02 $\mathrm{mmol} / \mathrm{l} \mathrm{L} 8040$ in $2 \mathrm{M}$ sodium dihydrogenorthophosphate were added in place of fenethazine since this, latter, compound was poorly extracted following the addition of sodium lauryl sulphate. - The contents of the test tube were vortex mixed (for $ᄃ$ $30 \mathrm{~s})$, centrifuged $(9950 \mathrm{~g}, 1 \mathrm{~min})$ and $100 \mu \mathrm{l}$ of the organic phase were then injected on to the column.

\section{INSTRUMENT CALIBRATION}

Standard solutions containing amiodarone and desethylamiodarone at concentrations of $1 \cdot 0,2 \cdot 0$ and $3.0 \mathrm{mg} / 1$ were prepared in analyte-free humano plasma, analyte-free pig myocardium digest and analyte-free human fat digest. A linear calibration graph with zero intercept and identical slope wasoํㅡㄹ obtained for amiodarone on the analysis of each set ${ }^{3}$ of standards. The extraction of desethylamiodarone was found to be $20 \%$ less from fat digest standards with respect of both plasma and heart digest stan $=\frac{-8}{8}$ dards. However, the tenfold dilution of fat digest in: analyte-free human plasma, used in routine applica tion of this method, eliminated this difference. The absolute recovery of amiodarone from plasma under? these conditions was $98 \cdot 6 \% \pm 3 \cdot 3$ (SD).

Results from diluted heart and fat digest standards were found to be directly comparable witho plasma standards. Plasma standards of $0 \cdot 5,1 \cdot 0,2 \cdot 0$ and $3.0 \mathrm{mg} / \mathrm{l}$ were routinely used for the measure- - . ment of concentrations of amiodarone and $\tilde{N}$ desethylamiodarone from all diluted tissue digests.

\section{Results}

A chromatogram obtained on analysis of an extract of human myocardium digest containing neither 0 amiodarone nor desethylamiodarone is shown in Fig. 2(b). Chromatograms obtained on analysis of extracts from digests of human heart and fat, and $\mathbb{D}$ rabbit liver tissue containing both analytes are $\frac{\odot}{\sigma}$ shown in Figs. 2(c)-(e). No endogenous sources of interference have been observed. A list of cardio- -0 

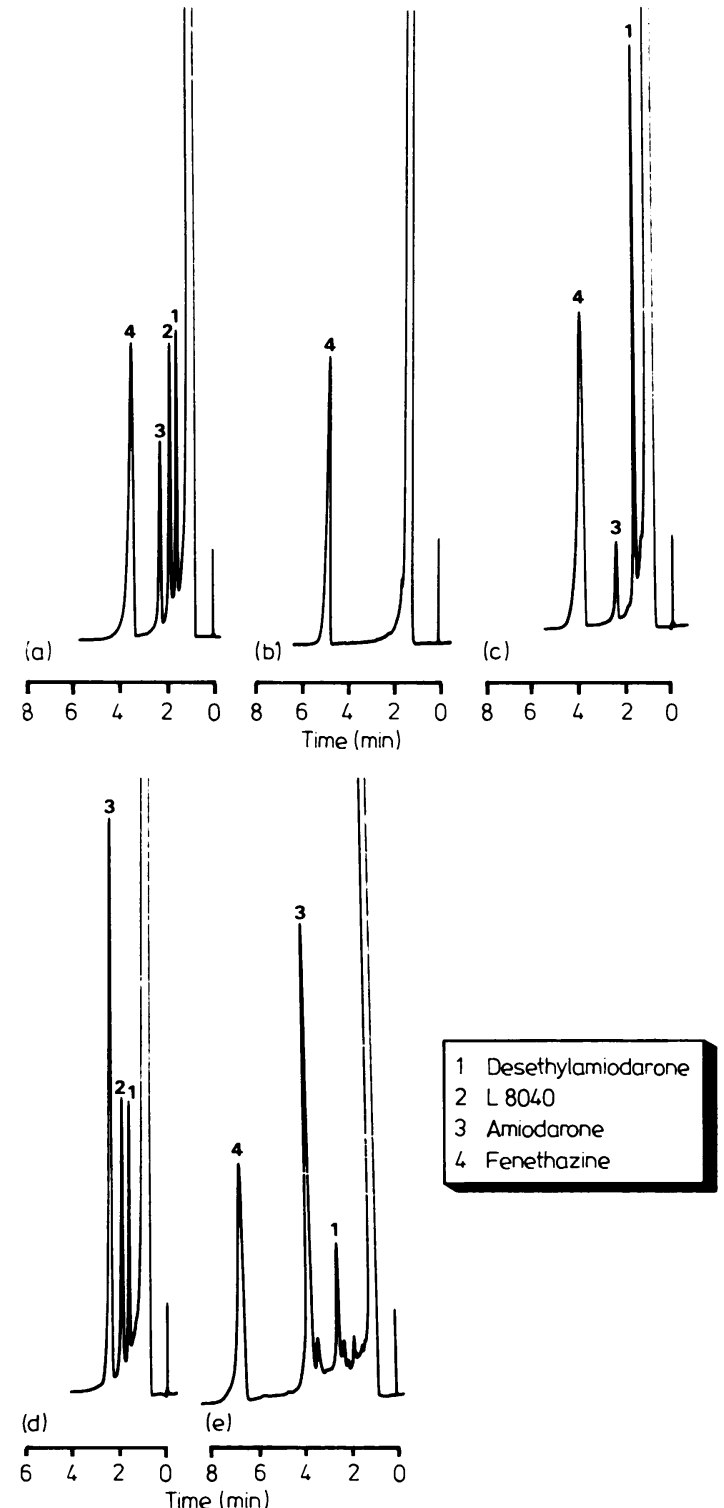

Fig. 2 (a) Chromatogram obtained on analysis of an extract of human plasma containing desethylamiodarone (1), L 8040 (2), amiodarone (3) and fenethazine (4). (b) Chromatogram obtained on analysis of an extract of a digest of drug-free human myocardium. (c) Chromatogram obtained on analysis of an extract of a digest of human myocardium containing amiodarone $(21 \mathrm{mg} / \mathrm{kg})$ and desethylamiodarone $(72 \mathrm{mg} / \mathrm{kg}$ ) Weight $100 \mathrm{mg}$ : Dilution $\times$ 100. (d) Chromatogram obtained on analysis of an extract of a digest of human fat containing amiodarone $(210$ $\mathrm{mg} / \mathrm{kg}$ ) and desethylamiodarone $(45 \mathrm{mg} / \mathrm{kg})$. Weight $30 \mathrm{mg}$ : Dilution $\times 120$. (e) Chromatogram obtained on analysis of an extract of a digest of rabbit liver containing amiodarone $(14 \mathrm{mg} / \mathrm{kg})$ and desethylamiodarone $(3.3 \mathrm{mg} / \mathrm{kg})$. Weight $115 \mathrm{mg}$ : Dilution $\times 7$.

active and other drugs which were potential sources of interference was noted in the definitive method for amiodarone measurement. ${ }^{3} \mathrm{~A}$ modification of this method enabling the simultaneous measurement of desethylamiodarone in the presence of common drugs uses an identical chromatographic system to the one described here. ${ }^{8}$ Tissue samples were analysed in duplicate and the concentrations of amiodarone and desethylamiodarone were calculated by comparing the peak area ratio of the analytes in the sample with the standard calibration graph. If the difference between duplicate analyses was greater than $10 \%$ the analysis was repeated. The final result was expressed in terms of $\mathrm{mg}$ analyte $/ \mathrm{kg}$ wet weight of tissue.

The reproducibility of the assay was assessed by digesting several pieces of tissue cut from the same organ. The results of the intra-assay reproducibility study for human heart and fat samples are summarised in Table 1 . The limit of sensitivity for the measurement of both compounds was $0.1 \mathrm{mg} / \mathrm{kg}$ wet weight using a $100 \mathrm{mg}$ tissue sample.

Neither incubating at $50^{\circ}$ for $16 \mathrm{~h}$ nor addition of enzyme solution affected the stability of amiodarone or desethylamiodarone in tissue digest spiked with these compounds.

This methodology has been applied successfully to the measurement of amiodarone and its desethyl metabolite in a wide variety of tissue samples from both humans and rabbits.

Table 2 shows the concentration of the two compounds in post-mortem samples collected from three cases in which the patients died whilst receiving amiodarone therapy.

JT A 67-year-old man, received amiodarone 400 mg daily for 6 months.

WH A 60-year-old man, received, on average, amiodarone $600 \mathrm{mg}$ daily for $\mathbf{4 0}$ days.

FB A 52-year-old man, received amiodarone 200 $\mathrm{mg}$ daily for 10 months.

Similar results were obtained from biopsy samples collected at the time of operation from two patients receiving amiodarone chronically (Table 3 ).

JA A 33-year-old woman, received amiodarone for $4.5 \mathrm{yr}, 800 \mathrm{mg}$ daily for 5 months before operation. JG A 60-year-old man, received amiodarone 600 mg daily for 33 days.

Finally, the compounds were measured in tissue samples collected at post-mortem from rabbits which had received $40 \mathrm{mg} / \mathrm{kg} /$ day amiodarone, peritoneally, for four weeks; the results are shown in Table 4.

\section{Discussion}

Use of enzymatic digestion of tissue samples prior to 
Table 1 Intra-assay reproducibility study

\begin{tabular}{|c|c|c|c|c|c|c|}
\hline \multirow[t]{2}{*}{ Compound } & \multicolumn{3}{|c|}{ Human myocardium } & \multicolumn{3}{|l|}{ Human fat } \\
\hline & Concentration & $C V \%$ & $n$ & Concentration & $C V \%$ & $n$ \\
\hline $\begin{array}{l}\text { Amiodärone } \\
\text { Desethylamiodarone }\end{array}$ & 202 & $\begin{array}{l}8 \cdot 6 \\
6 \cdot 6\end{array}$ & $\begin{array}{l}9 \\
9\end{array}$ & $\begin{array}{l}173 \\
43.9\end{array}$ & $\begin{array}{l}8 \cdot 3 \\
8 \cdot 3\end{array}$ & $\begin{array}{l}10 \\
10\end{array}$ \\
\hline
\end{tabular}

Tissue concentration $=\mathrm{mg} / \mathrm{kg}$ wet weight.

Table 2 Amiodarone and desethylamiodarone concentrations in human tissue at post-mortem

\begin{tabular}{|c|c|c|c|c|c|c|}
\hline \multirow[t]{2}{*}{ Tissue } & \multicolumn{2}{|l|}{ Patient JT } & \multicolumn{2}{|l|}{ Patient $W H$} & \multicolumn{2}{|l|}{ Patient FB } \\
\hline & Amiodarone & $\begin{array}{l}\text { Desethyl- } \\
\text { amiodarone }\end{array}$ & Amiodarone & $\begin{array}{l}\text { Desethyl- } \\
\text { amiodarone }\end{array}$ & Amiodarone & $\begin{array}{l}\text { Desethyl- } \\
\text { amiodarone }\end{array}$ \\
\hline $\begin{array}{l}\text { Heart } \\
\text { Skeletal muscle } \\
\text { Liver } \\
\text { Thyroid } \\
\text { Lung } \\
\text { Brain } \\
\text { Fat } \\
\text { Blood }\end{array}$ & $\begin{array}{c}35 \\
7 \cdot 5 \\
890 \\
15 \\
-\quad 3 \cdot 7 \\
245 \\
2 \cdot 1\end{array}$ & $\begin{array}{r}161 \\
33 \\
6500 \\
92 \\
-\quad \\
49 \\
87 \\
2.5\end{array}$ & $\begin{array}{c}21 \\
8 \cdot 1 \\
430 \\
12 \\
191 \\
8 \cdot 1 \\
210 \\
2 \cdot 3\end{array}$ & $\begin{array}{r}72 \\
19 \\
1520 \\
40 \\
810 \\
44 \\
45 \\
2 \cdot 1\end{array}$ & $\begin{array}{c}- \\
10 \\
188 \\
12 \\
183 \\
3 \cdot 0 \\
500 \\
-\end{array}$ & $\begin{array}{r}- \\
30 \\
570 \\
47 \\
620 \\
25 \\
112 \\
-\end{array}$ \\
\hline
\end{tabular}

Tissue concentration $=\mathrm{mg} / \mathrm{kg}$ wet weight.

Blood concentration $=\mathrm{mg} / \mathrm{l}$.

Table 3 Amiodarone and desethylamiodarone concentrations in human tissue at operation

\begin{tabular}{|c|c|c|c|c|}
\hline \multirow[t]{2}{*}{ Tissue } & \multicolumn{2}{|l|}{ Patient JA } & \multicolumn{2}{|l|}{ Patient JG } \\
\hline & Amiodarone & Desethylamiodarone & Amiodarone & Desethylamiodarone \\
\hline $\begin{array}{l}\text { Heart (LV) } \\
\text { Skeletal muscle } \\
\text { Skin } \\
\text { Fat } \\
\text { Blood }\end{array}$ & $\begin{array}{c}47 \\
23 \\
8 \cdot 3 \\
470 \\
2 \cdot 1\end{array}$ & $\begin{array}{c}95 \\
46 \\
24 \\
125 \\
2.4\end{array}$ & $\begin{array}{c}12 \\
8 \cdot 3 \\
4 \cdot 6 \\
120 \\
1 \cdot 4\end{array}$ & $\begin{array}{c}47 \\
12 \\
9 \cdot 3 \\
30 \\
1 \cdot 3\end{array}$ \\
\hline
\end{tabular}

Tissue concentration $=\mathrm{mg} / \mathrm{kg}$ wet weight.

Blood concentration $=\mathrm{mg} / \mathrm{l}$.

Table 4 Mean amiodarone and desethylamiodarone concentrations in rabbit tissue

\begin{tabular}{lcll}
\hline Tissue & Amiodarone & Desethylamiodarone & $n$ \\
\hline Skeletal muscle & 2.1 & 0.1 & 3 \\
Heart & 8.4 & 1.0 & 3 \\
Liver & 11.7 & 3.0 & 3 \\
Fat & 32.8 & 0.4 & 2 \\
Plasma & 1.4 & ND & 3 \\
\hline
\end{tabular}

Tissue concentrations $=\mathrm{mg} / \mathrm{kg}$ wet weight.

Plasma concentrations $=\mathrm{mg} / \mathrm{l}$.

ND $=$ not detected.

analysis for drugs is an established technique which enables small tissue samples to be handled more easily than by either blenders or homogenisers. ${ }^{910}$

The method reported here has proved both simple and reproducible, being applicable to a wide variety of tissues. Only a small tissue sample is required enabling quantitative measurement of biopsy as well as necropsy material.
These preliminary findings suggest an appre- $\frac{\overline{3}}{3}$ ciable accumulation of both amiodarone and desethylamiodarone in some tissues, with fat form- $\frac{0}{3}$ ing a potentially large tissue reservoir of the drug. Of note is the fact that the ratio of amiodarone to desethylamiodarone is lower in tissue than blood, $\frac{D}{0}$ with the exception of fat, this latter observation probably reflecting the greater lipid solubility of the $\widetilde{N}$ parent compound. In addition, it may be significant $N$ that the concentration of both compounds is high in $N$ the liver and the lung, tissues associated with ${ }^{\omega}$ amiodarone-induced adverse effects; raised serum $<$ asparate aminotransferase activities, related to high concentrations of amiodarone and desethy- $\mathbb{D}$ lamiodarone have been noted in some patients and the drug has been implicated in the development of pulmonary interstitial changes. ${ }^{11}$ The clinical $\stackrel{\mathbb{\Phi}}{\mathbb{D}}$ significance of these findings is under active con- $\frac{\stackrel{\rho}{\Phi}}{\mathbb{Q}}$ sideration and will be presented elsewhere (Adams, Storey, Holt, Campbell, in preparation).

Finally, the observation that the rabbit produces? 
very little of the desethyl metabolite could be of significance when using this animal as an experimental model for amiodarone. The pharmacological activity of desethylamiodarone is not yet known, but if it proves to have antiarrhythmic activity in man the rabbit would seem to be a poor model.

\section{References}

' Singh BN, Vaughan-Williams EM. The effect of amiodarone a new antianginal drug, on cardiac muscle. Br $J$ Pharmacol 1970;39:657-67.

${ }^{2}$ Flanagan RJ, Storey GCA, Holt DW, Farmer PB. Identification and measurement of desethylamiodarone in blood plasma specimens from amiodarone-treated patients. J Pharm Pharmacol 1982;34:638-43.

${ }^{3}$ Flanagan RJ, Storey GCA, Holt DW. Rapid high-performance liquid chromatographic method for the measurement of amiodarone in blood plasma or serum at the concentrations attained during therapy. J Chromatogr 1980;187:191-8.

4 Wilkinson PR, Rees JR, Storey GCA, Holt DW. Amiodarone: prolonged elimination following cessation of chronic therapy. Am Heart $J$ (in press).

${ }^{5}$ Holt DW, Storey GCA. Measurement of amiodarone. In: Krikler DK, Chamberlain DA, McKenna WJ, eds.
Amiodarone and arrhythmias Oxford: Pergamon Press, 1983:11-17.

- Broekhuysen J, Laruel R, Sion R. Recherches dans la serie des benzofurannes XXXVII. Etude comparee du transit et du metabolisme de l'amiodarone chez diverses especes animales et chez l'homme. Arch Int Pharmacodyn 1969;177:340-59.

' Riva E, Gerna M, Negroz P, Urso R, Bartosek I, Guartani A. Pharmacokinetics of amiodarone in rats. $J$ Cardiovasc Pharmacol 1982;4:270-5.

storey GCA, Holt DW, Holt P, Curry PVL. High-performance liquid chromatographic measurement of amiodarone and its desethyl metabolite: Methodology and preliminary observations. Therap Drug Mon 1982;4:385-8.

9 Osselton MD, Hammond MD, Twitchett PJ. The extraction and analysis of benzodiazepines in tissues by enzymatic digestion and high-performance liquid chromatography. J Pharm Pharmacol 1977;29:460-2.

${ }^{10}$ Holt DW, Loisou M, Wyse RKH. Gas liquid chromatographic measurement of lignocaine in small samples of canine myocardium after enzymatic digestion.J Clin Pathol 1979;32:225-8.

"Harris L, McKenna WJ, Rowland E, Holt DW, Storey GCA, Krikler DM. Amiodarone: side effects of long term therapy. Circulation 1983;67:45-51.

Requests for reprints to: Dr DW Holt, Poisons Unit, Guy's Hospital, London SE1 9RT, England 